\title{
Studi Pengaruh Paparan Radiasi Gamma Dan Ekstrak Kulit Manggis (Garcinia Mangostana) Terhadap Gambaran Mikroskopis Dan Kadar Sgpt Organ Hepar Mencit (Mus Musculus)
}

\author{
Kadek Ayu Cintya Adelia \\ Program Studi Fisika, Universitas San Pedro, \\ Jl. Veteran no 1-4 Fatululi, Kupang, Nusa Tenggara Timur \\ Email: lidyakadekayu@gmail,com
}

\begin{abstract}
This study examines the effect of the use of gamma radiation in the health sector, one of which is the use of gamma rays in the radiotherapy process. Irradiation into the body can cause the emergence of free radicals in the body which can harm other organs around the irradiation target. This study aims to determine the effect of exposure to gamma radiation on the liver of mice and the hepatoprotective properties of mangosteen peel extract (Garcinia mangostana) in reducing the resulting cell damage. This study was conducted by giving mice mangosteen peel extract with 5 different doses from those given 40 minutes of radiation exposure with a total dose of $268 \mu S v$ for 14 days, then the SGPT (serum glutamic pyruvic transaminase) levels were measured and cell damage figures from histopathological preparations. The results showed that before being given mangosteen peel extract, total damage to hepatocyte cells was $47.34 \%$. After being given mangosteen peel extract, total damage to hepatocyte cells was 23.42\%. Meanwhile, the SGPT level decreased to $77.7 \mathrm{U} / \mathrm{L}$ from the initial level of 128.67 $U / L$. This proves that mangosteen peel extract has hepatoprotective properties that can reduce cell damage due to exposure to gamma radiation.
\end{abstract}

Keywords: Mangosteen Extract, Mice (Mus musculus), Liver Organs, Gamma Radiation, SGPT

\begin{abstract}
Abstrak: Penelitian ini mengkaji pengaruh penggunaan radiasi gamma di bidang kesehatan, salah satunya adalah penggunaan sinar gamma dalam proses radioterapi. Penyerapan energi radiasi ke dalam tubuh dapat menyebabkan munculnya radikal bebas dalam tubuh yang dapat merugikan organ lain di sekitar target penyinaran. Penelitian ini bertujuan untuk mengetahui pengaruh paparan radiasi gamma terhadap hepar mencit dan sifat hepatoprotektif ekstrak kulit manggis(Garcinia mangostana) dalam mengurangi kerusakan sel yang ditimbulkan. Penelitian ini dilakukan dengan memberikan ekstrak kulit manggis 5 dosis varian berbeda ke mencit dan diberi paparan radiasi selama 40 menit dengan dosis total $268 \mu \mathrm{Sv}$ selama 14 hari, kemudian diukur kadar SGPT (serum glutamic pyruvic transaminase) dan jumlah kerusakan sel dari preparathistopatologis. Hasil penelitian menunjukkan bahwa sebelum diberikan ekstrak kulit manggis, kerusakan total sel hepatosit sebesar 47,34\%. Setelah diberikan ekstrak kulit manggis, kerusakan total sel hepatosit sebesar 23,42\%. Sementara itu, kadar SGPT turun menjadi 77,7 U/L dari kadar awal 128,67 U/L. Hal ini membuktikan bahwa ekstrak kulit manggis memiliki sifat hepatoprotektif yang dapat mengurangi kerusakan sel akibat paparan radiasi gamma.
\end{abstract}

Kata kunci: Ekstrak Kulit Manggis, Mencit (Mus musculus), Organ Hepar, Radiasi Gamma, SGPT

\section{PENDAHULUAN}

Sinar gamma adalah gelombang elektromagnetik yang sepenuhnya dapat melewati tubuh manusia, sinar gamma paling sering digunakan dalam bidang kesehatan khususnya dalam proses radioterapi kanker. Akibat dari lewatnya gelombang elektromagnetik maka akan terjadi proses ionisasi, dan juga berpotensi terhadap organ lain yang ada di dalam tubuh(Rahmouni, F., Badraoui, R., Amri, N., Elleuch, A., El-Feki, A., Rebai, T., Saoudi, 2019).Dalam (Zahedi, R., Bakhshandeh, M., Sabouri, Ahmadi, 2016)ketika terapi kanker toraks dan paru-paru didapati terdapat kerusakan pada organ hepar dilihat dari meningkatnya kadar SGPT. Dalam 
hal ini sel yang tidak langsung terpapar akan memberi respon seperti halnya terpapar secara langsung, hal ini terjadi karena ketika bereaksi dengan organ didalam tubuh radiasi akan berinteraksi dengan $\mathrm{H}_{2} \mathrm{O}$ hal ini dikarenakan dalam tubuh manusia terdiri dari $80 \%$ air, hal ini juga menyebabkan timbulnya radikal bebas atau Reactive Oxygen Species (ROS). Ketika ada ROS maka akan menyebabkan kerusakan oksidatif pada biomolekul seperti protein, DNA, lipoprotein dan lipid (Giardi, M.T., Touloupakis, E., Bertolotto, D., Mascetti, 2013). Kerusakan seperti itu dikaitkan dengan banyak penyakit degeneratif,termasuk aterosklerosis, kanker, asma, artritis, serangan jantung,kerusakan ginjal, kerusakan hati, dan induksi apoptosis (El-Bahr, 2013).

Organ Hepar sangat peka terhadap sinar radiasi dan kerusakan hepar merupakan komplikasi klinis serius yang dihasilkan dari iradiasi sinar gamma (Malik, I.A., Moriconi, F., Sheikh, N., Naz, N., Khan, S., Dudas, J., Mansuroglu, T. \& C.F., Rave-Fränk, M., Christiansen, H., Ramadori, 2010). ROSdapat merangsang sel inflamasi untuk membunuh hepatosit dan sel hati lainnya (Jaechke, 2011). Hepar mempunyai kemampuan untuk meregenerasi, namun dalam beberapa kasus yang ada sel hati yang mati atau sakit akan diganti dengan jaringan hati yang baru, namun ketika terdapat radikal bebas dalam organ hepar maka organ hepar akan sulit untuk meregenerasi diri (Fouad, Alhatem, Abdel-Gaber, \& Ataya, 2019)

Radikal bebas merupakan molekul atau atom tidak stabil yang mempunyai sekelompok atom dengan elektron yang tidak berpasangan sehingga memiliki kecenderungan untuk menarik elektron dari molekul lain. Ketika radikal bebas menarik elektron, ia akan memicu reaksi berantai yang menambah jumlah radikal bebas. Radikal bebas ini kemudian akan berinteraksi dengan materi biologis sel, jika radikal bebas tidak diinaktivasi, reaksinya akan dapat merusak seluruh tipe makromolekul seluler termasuk protein, lipid dan asam nukleat dan karbohidrat (Dawn., 2000).

Salah satu indikator dalam menguji kerusakan organ hepar adalah SGPT (serum glutamic pyruvic transaminase) merupakan enzim yang berada di dalam sel hati (hepatosit), peningkatan kadar SGPT dapat mengindikasikan tingginya kerusakan pada organ hati, dosis radiasi selama 10 menit dapat menyebabkan tingginya kadar SGPT mencit sebesar 2,4 \% dari kadar normal (Adelia, Widodo, \& Noor, 2019)

Antioksidan merupakan sifat dari sekumpulan senyawa-senyawa yang dapat mengurangi proses oksidasi atau terbentuknya radikal bebas,antioksidan biasa ditemukan dalam golongan buah dan sayur. Salah satu buah yang dapat dijadikan antioksidan adalah buah manggis, manggis memiliki senyawa antioksidan yang tinggi terutama pada kulit buahnya diantara lain flavonoid, Alkaloid, saponin tannin ,polifenol dan xanthone. Penelitian (Arsana, 2016) menunjukkan peningkatan dosis kulit manggis mampu menurunkan kerusakan sel organ hati akibat paparan isoniazid.

Dalam studi ini diteliti mengenai kemampuan mengurangi kerusakan dari ekstrak kulit manggis, serta pengaruh peningkatan dosis ekstrak yang diberikan terhadap perubahan gambaran mikroskopis dan kadar SGPT organ hepar mencit.

\section{METODE PENELITIAN}

\subsection{Pemeliharaan Mencit}

Pada penelitian ini digunakan 55 ekor mencit jantan dengan berat sekitar 18-20 gram. Mencit diperoleh dari laboratorium fisiologi hewan UIN Malang, mencit diberi pakan dan minum secukupnya kemudian mencit diaklimatisasi. 


\subsection{Pengelompokkan Mencit}

Mencit dikelompokkan menjadi 3 kelompok yaitu kelompok kontrol, kelompok radiasi dan kelompok radiasi dan pemberian ekstrak kulit manggis.

\subsection{Pemberian Paparan Radiasi}

Sumber radiasi dalam penelitian ini yaitu Cs-137,Am-241, Co-60 dan Na-22 sumber radiasi gamma tersebut kemudian diletakkan dalam tempat berbentuk setengah lingkaran yang terbuat dari kayu dan pada bagian tengah kayu terdapat lubang untuk menempatkan sumber radiasi. Kemudian mencit diletakkan di bawah sumber radiasi dan dibiarkan terpapar selama waktu yang ditentukan yaitu 10,20,30,40 dan 50 menit.

\subsection{Pemberian Ekstrak Kulit Manggis}

Ekstrak kulit manggis akandicampur dengan air sebagai pelarut. Ekstrak kemudian diberikan kepada mencit secara oral dengan menggunakan sonde lambung dengan dosis yang telah ditetapkan sebelumnya, satu kali sehari selama 14 hari. Ekstrak kulit manggis diberikan variasi dosis yaitu 2,9 mg, 3,4 mg, 3,9 mg, 4,4 mg dan 4,9 mg.

\subsection{Analisis Data}

Pengamatan menggunakan software Image Raster kemudian diolah menggunakan Microsoft office excel. Perhitungan persentase kerusakan sel hepar menggunakan persamaan :

$$
\% \text { Kerusakan }=\frac{\text { Jumlah Sel Rusak }}{\text { Jumlah Sel dalam } 1 \text { lapang pandang }} x 100 \%
$$

Interpretasi data dilakukan dengan melihat bentuk pola yang dihasilkan dari grafik hasil ploting. Pola yang dihasilkan dari grafik akan menunjukkan hubungan dan korelasi di antara parameter kerusakan sel, dalam hal ini yaitu lamanya paparan radiasi, kadar SGPT pada organ hepar mencit, dosis ekstrak, dan presentase kerusakan sel.

\section{HASIL DAN PEMBAHASAN}

\subsection{Pengamatan Pada Organ Hepar Mencit}

Pada penelitian ini diperoleh kadar SGPT dan persentase kerusakan sel hepar mencit pada kondisi normal, dipapari radiasi gamma dengan 5 variasi dosis paparan, dan setelah diberi ekstrak kulit manggis.

Setelah dilakukan pengamatan pada sel hepatosit organ hepar mencit (Mus musculus) dapat dilihat bahwa paparan radiasi gamma menyebabkan kerusakan pada sel hepatosit organ hepar karena terdapat beberapa jenis kerusakan yang terjadi baik pada kelompok kontrol maupun yang diberikan paparan radiasi gamma.Jenis kerusakan organ hepar mencit yang ditemukan pada penelitian ini antara vena centralis, sel binuklear dan degenerasi parenkim.

Dari hasil pengamatan gambaran histologi sel hepar mencit menunjukkan bahwa paparan radiasi gamma menyebabkan kerusakan sel hepar mencit, untuk dosis yang diterima mencit selama 14 hari adalah $65,61 \mu \mathrm{Sv}, 131,23 \mu \mathrm{Sv}, 201 \mu \mathrm{Sv}, 268 \mu \mathrm{Sv}, 337 \mu \mathrm{Sv}$ untuk rentang waktu 10 menit, 20 menit, 30 menit, 40 menit dan 50 menit. 


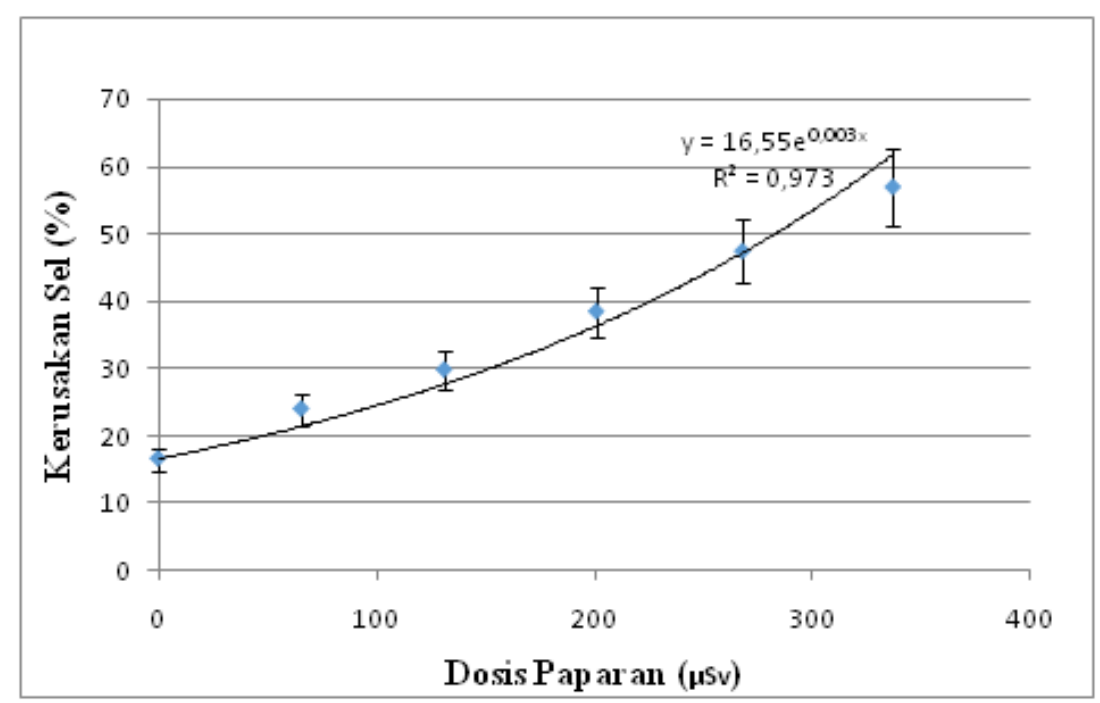

Gambar 1. Kerusakan sel bertambah seiring kenaikan dosis paparan.

Dari grafik dapat dilihat bahwa semakin besar dosis paparan radiasinya, semakin tinggi pula kerusakan totalnya. Dosis paparan merupakan akumulasi dari sumber radioaktif yaitu 65,61 $\mu \mathrm{Sv}$ untuk waktu 10 menit paparan, 131,23 $\mu$ Sv untuk waktu 20 menit paparan, $201 \mu \mathrm{Sv}$ untuk waktu 30 menit paparan, $268 \mu \mathrm{Sv}$ untuk waktu 40 menit paparan, $337 \mu \mathrm{Sv}$ untuk waktu 50 menit paparan.

Pada hewan kontrol, kerusakan selnya mencapai 16,55 \%. Hal ini disebabkan karena kondisi mencit yang berbeda satu sama lain pada proses aklimatisasi. Pada paparan radiasi dengan dosis paparan $65,61 \mu \mathrm{Sv}$ selama 10 menit, kerusakan sel mencapai 23,93\%. Kenaikan persentase kerusakan sel juga terjadi ketika mencit terpapar radiasi gamma dengan dosis $131,23 \mu \mathrm{Sv}$ selama 20 menit, yaitu sebesar 29,74 \%. Pada paparan radiasi gamma dengan dosis $201 \mu \mathrm{Sv}$ selama 30 menit, kerusakan sel mencapai 38,39\% dan kenaikan presentase kerusakan sel yang terpapar radiasi gamma dengan dosis $268 \mu \mathrm{Sv}$ dan $337 \mu \mathrm{Sv}$ selama 40 menit dan 50 menit berturut-turut yaitu sebesar $47,34 \%$ dan $56,86 \%$.

Pada menit ke-10, mencit mulai menerima paparan radiasi, sehingga radikal bebas yang disebabkan oleh paparan radiasi gamma mulai muncul dan berinteraksi dengan sel dan memicu kerusakan pada sel. Pada menit-menit selanjutnya, kerusakan sel akan terus mengalami kenaikan. 


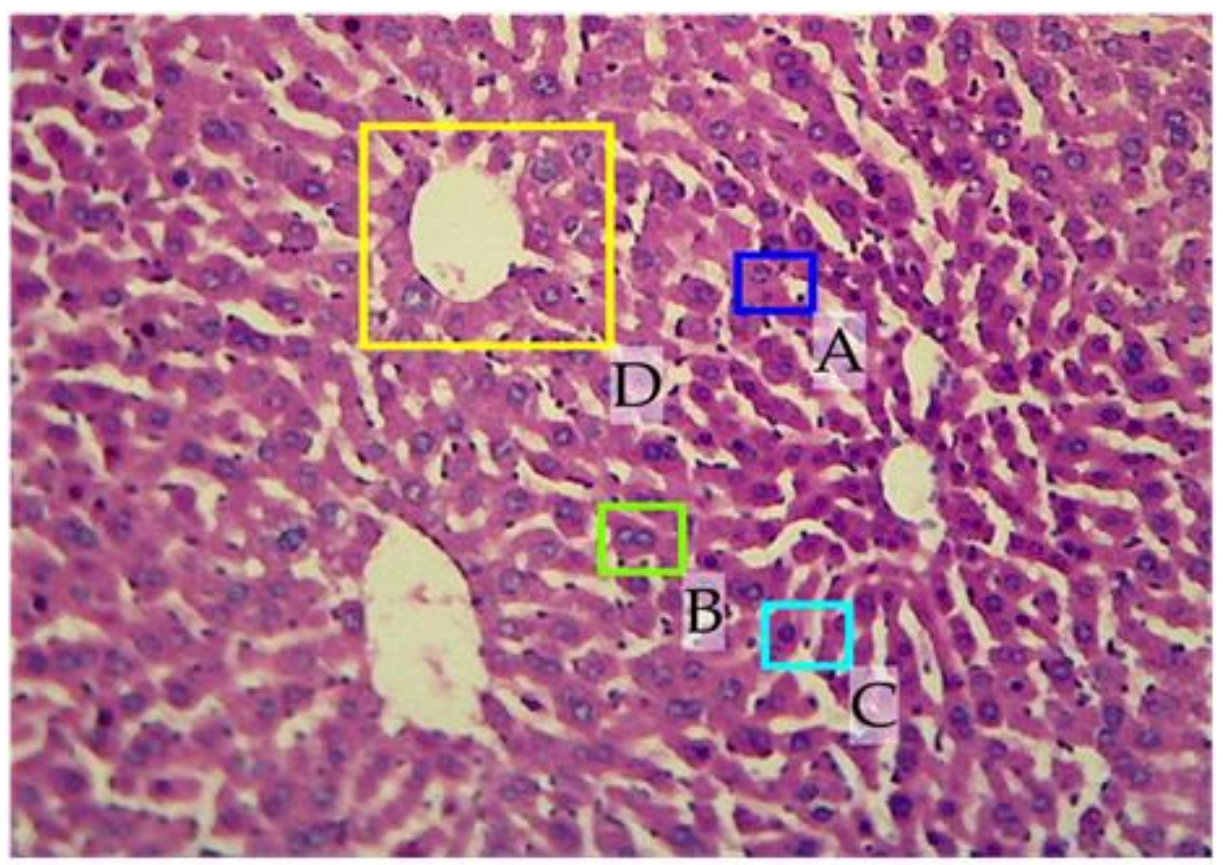

Gambar 2. Gambaran Mikroskopis Organ Hepar yang dipapari Radiasi Gamma.

Parameter lain yang juga dapat menunjukkan adanya kerusakan pada organ hepar akibat paparan radiasi ini adalah kadar enzim SGPT dalam darah. Enzim sendiri merupakan protein katalisator yang dihasilkan oleh sel hidup dan secara umum ada di dalam sel. Ketika dalam keadaan normal terdapat keseimbangan antara pembentukan enzim dengan penghancurannya, tetapi apabila terjadi kerusakan sel maka enzim akan keluar ke ruang ekstra sel menuju ke aliran darah sehingga hal ini dapat digunakan sebagai sarana untuk membantu mendiagnostik penyakit hati (Lee., 2016).

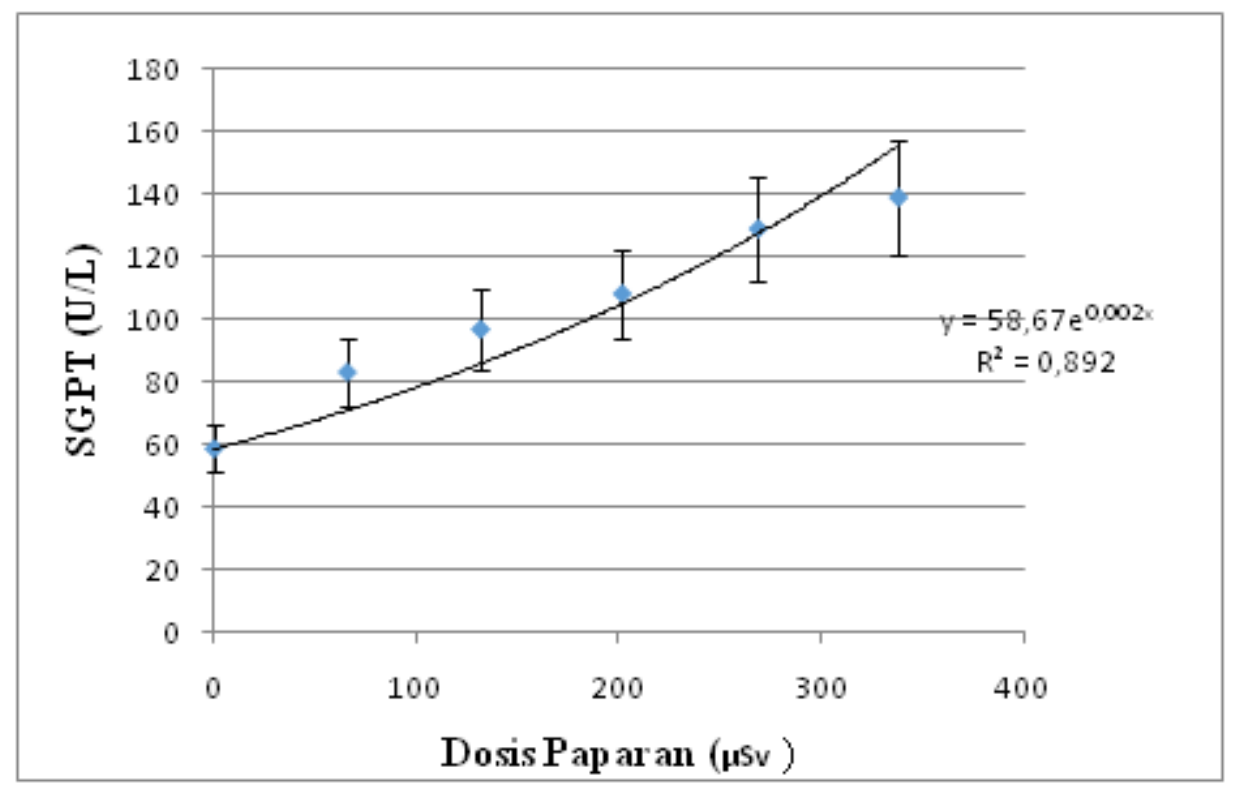

Gambar 3. Kadar SGPT Organ Hepar Mencit yang dipapari Radiasi Gamma. 
Pada pemaparan dengan dosis $337 \mu$ Sv selama 50 menit, besarnya kadar SGPT pada darah adalah 138,67 U/L, sedangkan pada keadaan normal kadar SGPT hepar hanya sebesar $58,67 \mathrm{U} / \mathrm{L}$.

\subsection{Pengaruh Ekstrak Kulit Manggis Terhadap Kerusakan Organ Hepar mencit}

Berdasarkan penelitian ini, dapat dilihat bahwa jumlah sel normal jauh lebih banyak dibandingkan dengan tahap sebelumnya.

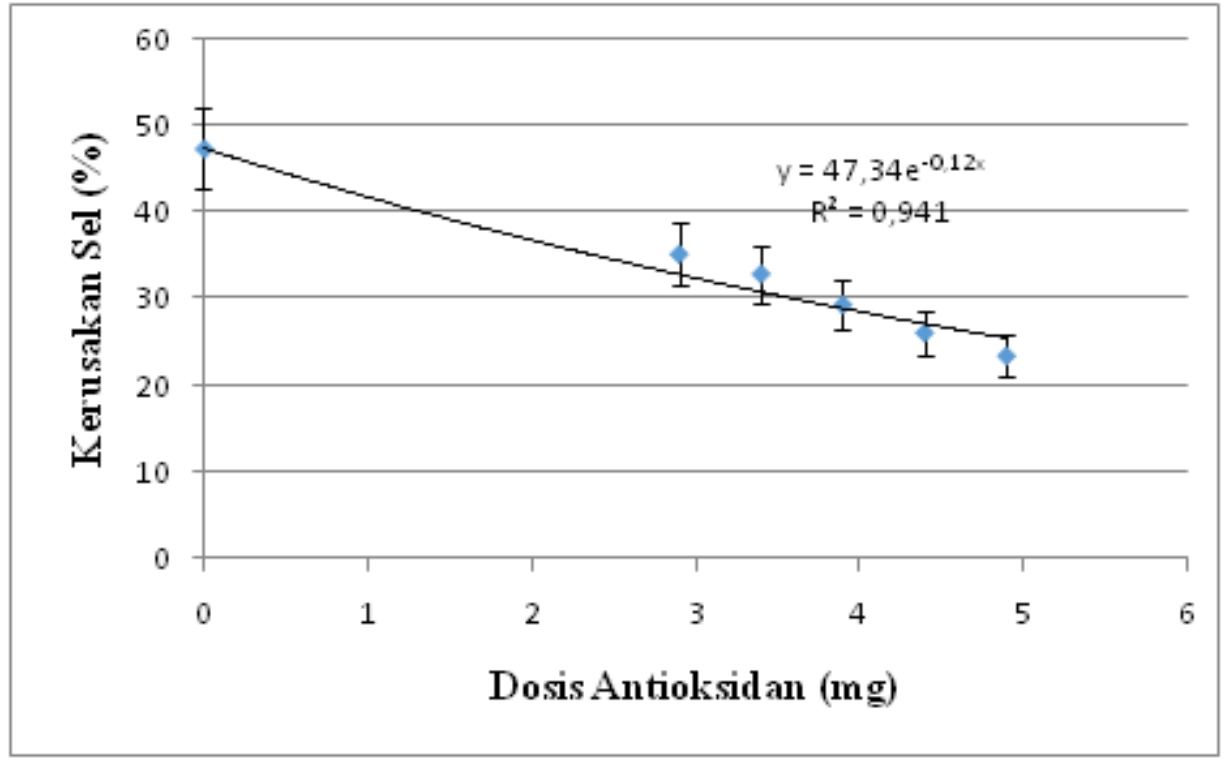

Gambar 4. Kadar SGPT Organ Hepar Mencit yang diberi Ekstrak Kulit Manggis

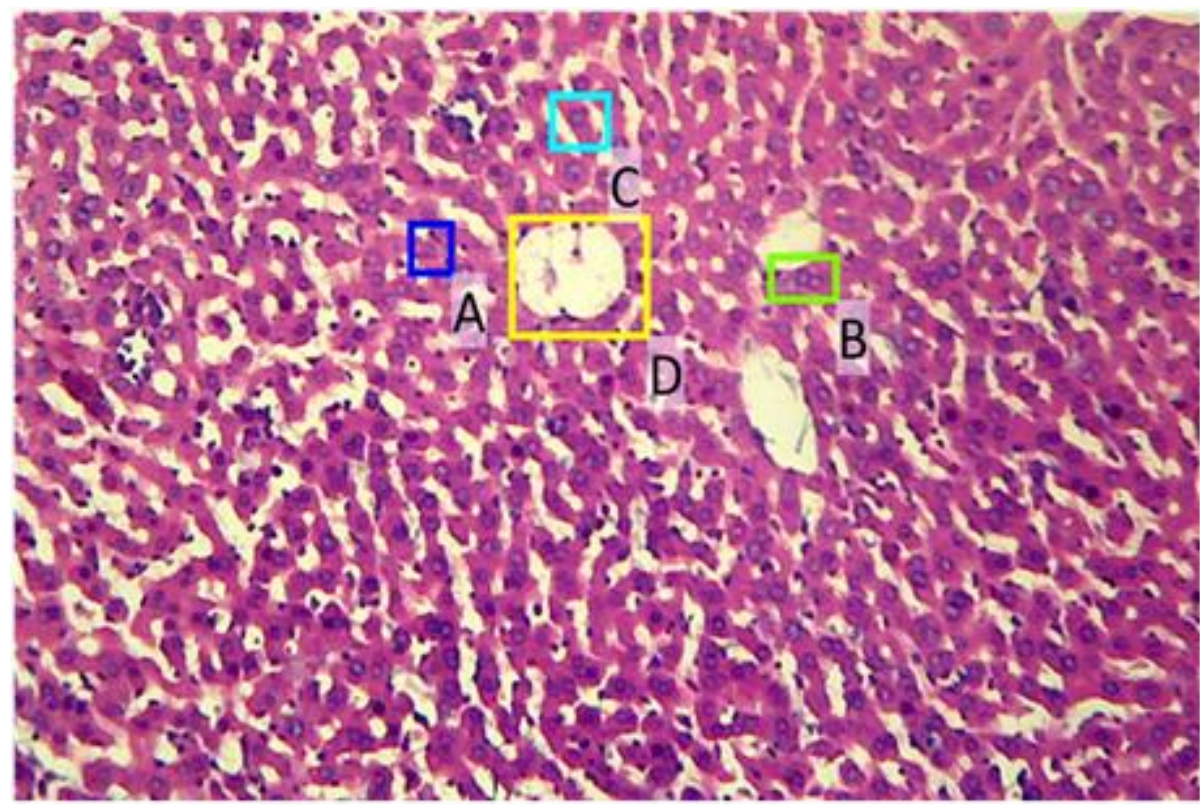

Gambar 5. Gambaran mikroskopis sel hepar mencit yang diberi ekstrak kulit manggis

Pemberian ekstrak kulit manggis sangat berpengaruh terhadap kerusakan sel hepar mencit. Hal ini ditunjukkan pada Gambar 4 dan 5 di mana mencit yang diberi ekstrak antioksidan kemudian dilakukan pemaparan radiasi gamma, terjadi penurunan persentase kerusakan sel dari 47,34 \% menjadi 23,42\%. Hasil tersebut juga diperkuat dengan gambaran mikroskopissel 
hepar mencit yang terlihat pada Gambar 5.Hal ini juga membuktikan bahwa selain mengurangi radikal bebas, antioksidan tersebut juga memberi sel ion, nutrisi, dan juga zat lain yang dibutuhkan sel untuk melakukan metabolisme, sehingga sel mengalami perbaikan seiring dengan bertambahnya dosis yang diberikan.

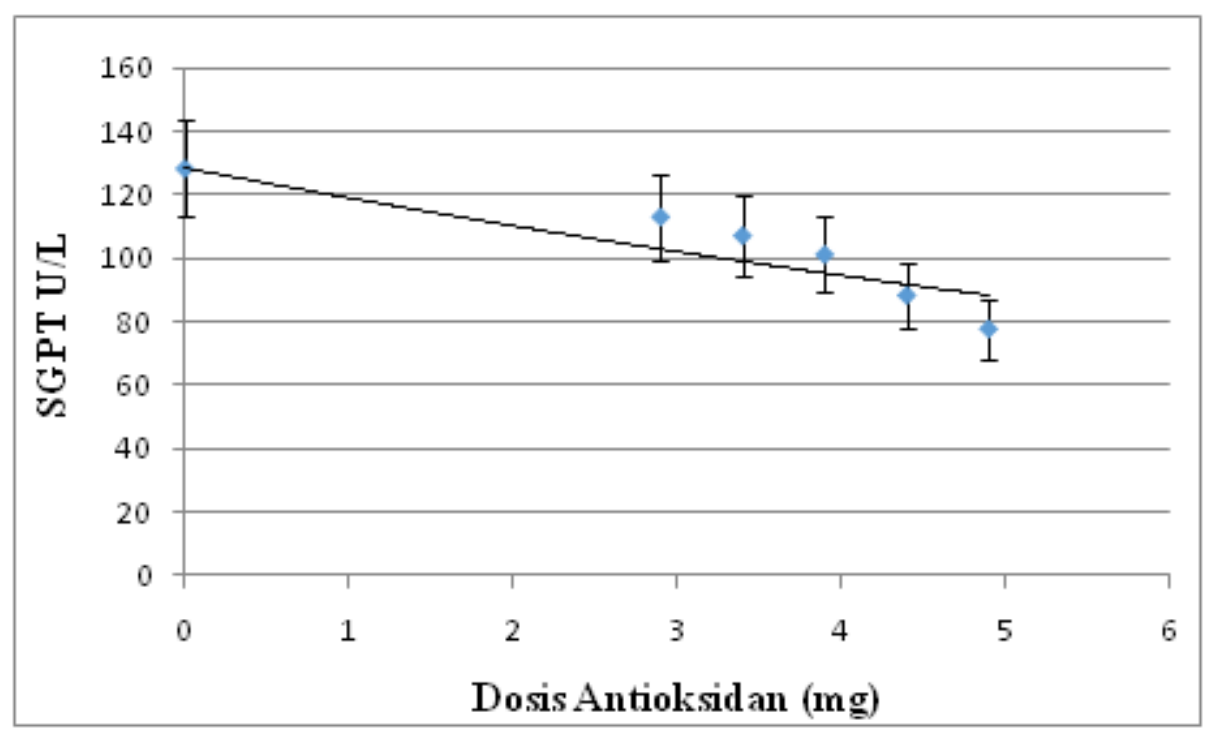

Gambar 6. Hubungan pemberian ekstrak kulit manggis terhadap kadar SGPT

Peningkatan kadar SGPT adalah salah satu respons akibat paparan radiasi gamma. Mekanisme kerusakan sel hepar yang disebabkan radikal bebas sama dengan mekanisme kerusakan sel pada umumnya (Kazue Honma, Michiko Kamiku,Kazuki Mochizuki, 2017). Radikal bebas pertama kali akan menyerang membran sel hati yang tersusun atas fosfolipid sehingga menyebabkan gangguan permeabilitas membran sel, karena permeabilitas membran sel terganggu maka terjadi influx kalsium yang berasal dari ekstrasel maupun pelepasan kalsium dari mitokondria dan reticulum endoplasma. Peningkatan influx kalsium akan memicu pengaktifan sejumlah enzim perusak seperti protease yang dapat merusak DNA, ketika DNA rusak, poliribosom meningkat dan terjadi pengosongan NAD yang mengakibatkan kerusakan pada sel hati atau nekrosis, yang ditandai dengan tingginya kadar glutamate piruvat transaminase dalam serum akibat lisosom dalam membran plasma mengalami lisis (Umniyah, 2007).

\subsection{Pengaruh Ekstrak Kulit Manggis dalam Mengurangi Radikal Bebas}

Kulit manggis mengandung berbagai macam senyawa antioksidan yang berguna bagi tubuh, antara lain flavonoid, alkaloid, saponin, polifenol, dan tannin dan xantone.Flavonoid merupakan senyawa yang paling berpengaruh dalam pemulihan sel hepatosit mencit. Banyak penelitian yang telah menyatakan bahwa senyawa flavonoid memiliki potensi sebagai antioksidan karena memiliki gugus hidroksil yang terikat pada karbon cincin aromatik sehingga dapat menangkap radikal bebas yang dihasilkan dari reaksi peroksidasi lemak, senyawa flavonoid akan menyumbangkan satu atom hidrogen untuk menstabilkan radikal peroksi lemak (Olagaray dkk., 2019).

Posisi dan jumlah gugus hidroksil mempengaruhi aktivitas senyawa antioksidan flavonoid. Flavonoid bekerja dengan carascavenging dimana ia akan menangkap radikal bebas dengan menggunakan gugus hidroksilnya. 


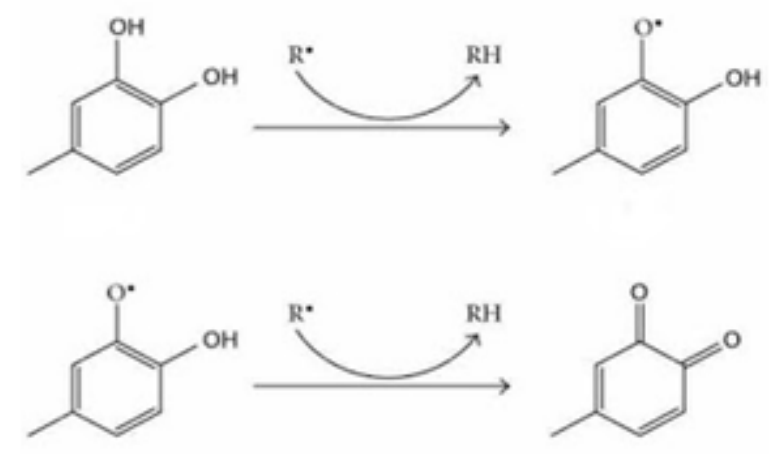

Gambar 7. Proses Scavenging oleh Flavonoid (Perez-vizcaino \& Fraga, 2018)

Flavonoid menyumbangkan atom $\mathrm{H}$ untuk menangkap radikal bebas, sehingga radikal bebas yang semula tidak stabil akan menjadi stabil. Atom $\mathrm{H}$ akan berikatan dengan radikal bebas dan menghasilkan RH. Hal ini menyebabkan flavonoid juga menjadi radikal karena kehilangan satu atom $H$. Namun, flavonoid akan menjadi lebih stabil, setelah melepas atom $\mathrm{H}$ lain untuk menangkap radikal bebas (Perez-vizcaino \& Fraga, 2018).

Penurunan kadar kadar SGPT juga terjadi karena senyawa yang terkandung dalam ektrak kulit manggis bekerja sebagai antioksidan dengan cara mendonorkan elektronnya kepada radikal bebas sehingga dapat mengurangi peroksidasi lipid membran pada sel hepar (Putri., 2015).

Sifat antioksidan senyawa yang terkandung dalam ekstrak kulit manggis dikaitkan dengan adanya bahan aktif terutama dari kulit buah. Bahan aktif yang telah berhasil diidentifikasi dari kulit buah manggis berupa sejumlah besar senyawa xanthone, di antaranya 8hydroxycudraxanthone $\mathrm{G}$, mangostingone mangostin, smeathxanthone A, dan tovophyllin A. (Dewi dkk, 2013). Di antara senyawa xanthone adanya gugus hidoksil $(\mathrm{OH})$ memungkinkan senyawa tersebut bersifat antioksidan dengan cara mendonorkan elektronnya kepada radikal bebas untuk membentuk produk akhir yang stabil sehingga tidak terjadi reaksi oksidasi lebih lanjut (Liü, et al 2010).

\section{KESIMPULAN}

Ekstrak kulit manggis memiliki sifat hepatoprotektif karena mampu mengurangi kerusakan organ hepar dilihat dari menurunnya kerusakan yang ditimbulkan diliohat dari gambaran mikroskopis yaitu dari 47,34 \% menjadi 23,42 \% dan kadar SGPT dari 128,67 menjadi 77,7 $\mathrm{U} / \mathrm{L}$.

\section{SARAN}

Perlu dilakukan penelitian lebih lanjut tentang efek paparan radiasi gamma terhadap kadar SOD (Superoxide dismutase) serta perlu diteliti jenis radikal bebas yang terkandung pada hepar mencit serta pengaruh radiasi gamma terhadap organ lainnya.

\section{DAFTAR PUSTAKA}

Adelia, K. A. C., Widodo, C. S., \& Noor, J. A. E. (2019). Effect Extract of Soursop Leaf (Annona Muricata) and Mangosteen Peel (Garcinia Mangostana) on SGPT Level in the Liver of Mice (Mus Musculus) Exposure to Gamma Radiation. International Research Journal of Advanced Engineering and Science, 4(1), 244-246.

Arsana, I. N. (2016). Ekstrak Kulit Buah Manggis ( garcinia Mangostana) Memperbaiki Fungsi Hati SElama Aktifitas Fisik. LPPM UNMAS, 11, 103-111. 
Dawn, B., Marks, A. D. M. dan C. M. S. (2000). Kedokteran dasar sebuah pendekatan klinis. jakarta: ECG.

Dewi, I. D. A. D. Y., Astuti, K. W. dan Warditiani, N. K. (2013). Skrining Fitokimia Ekstrak Etanol 95\% Kulit Buah Manggis (Garcinia mangostana L. Jurnal Farmasi Udayana, 2,4 .

El-Bahr, S. M. (2013). Biochemistry of free radicals and oxidative stress. Forensic Sci. International, 1(5), 111-117.

Fouad, D., Alhatem, H., Abdel-Gaber, R., \& Ataya, F. (2019). Hepatotoxicity and renal toxicity induced by gamma-radiation and the modulatory protective effect of Ficus carica in male albino rats. Research in Veterinary Science, 125(April), 24-35. https://doi.org/10.1016/j.rvsc.2019.05.010

Giardi, M.T., Touloupakis, E., Bertolotto, D., Mascetti, G. (2013). Preventive or potential therapeutic value of nutraceuticals against ionizing radiation-induced oxidative stress in exposed subjects and frequent fliers. Int. J. Mol. Sci., 4(8), 17168-17192.

Jaeschke, H. (2011). Reactive oxygen and mechanisms of inflammatory liver injury: present concepts. Journal Gastroenterol. Hepatology, 26(1), 173-179.

Kazue Honma, Michiko Kamiku,Kazuki Mochizuki, T. G. (2017). Insulin-induced inhibition of gluconeogenesis genes, including glutamic pyruvic transaminase 2, is associated with reduced histone acetylation in a human liver cell line. Journal Metabolism, 71, $118-124$.

Lee, H., Choi, Y. H., Sung, H. H., Han, D. H., Jeon, H. G., Jeong, B. C., ... Choi, H. Y. (2016). De Ritis Ratio (AST/ALT) as a Significant Prognostic Factor in Patients With Upper Tract Urothelial Cancer Treated With Surgery. Clinical Genitourinary Cancer, 115(3), 379-385. https://doi.org/10.1016/j.clgc.2016.08.023

Lü, J., Lin, P. H., Yao, Q., \& Chen, C. (2010). Chemical and molecular mechanisms of antioxidants: experimental approaches and model systems. 14(4), 840-860. https://doi.org/10.1111/j.1582-4934.2009.00897.x

Malik, I.A., Moriconi, F., Sheikh, N., Naz, N., Khan, S., Dudas, J., Mansuroglu, T., H., \& C.F., Rave-Fränk, M., Christiansen, H., Ramadori, G. (2010). Single-dose gammairradiation induces up-regulation of chemokine gene expression and recruitment of granulocytes into the portal area but not into other regions of rat hepatic tissue. American Journal Pathology, 176(4), 1801-1815.

Olagaray, K. E., \& Bradford, B. J. (2019). Plant flavonoids to improve productivity of ruminants - A review. Animal Feed Science and Technology, 251, 21-36. https://doi.org/10.1016/j.anifeedsci.2019.02.004

Perez-vizcaino, F., \& Fraga, C. G. (2018). Research trends in fl avonoids and health. Archives of Biochemistry and Biophysics, 646(March), 107-112. https://doi.org/10.1016/j.abb.2018.03.022

Putri, I. P. (2015). EFFECTIVITY OF XANTHONE OF MANGOSTEEN ( Garcinia mangostana L .) RIND AS ANTICANCER. Jurnal; Kedokteran Unila, 4, 33-38.

Rahmouni, F., Badraoui, R., Amri, N., Elleuch, A., El-Feki, A., Rebai, T., Saoudi, M. (2019). Hepatotoxicity and nephrotoxicity in rats induced by carbon tetrachloride and the 
protective effects of Teucrium polium and vitamin C. Toxicol. Mech. Methods 29, 5, 313-321.

Umniyah, I. . (2007). Pengaruh pemberian teh hijau terhadap kadra transaminase pada hepar mencit diabetes. UIN maulana malik ibrahim Malang.

Zahedi, R., Bakhshandeh, M., Sabouri, Ahmadi, R. (2016). Early Effect of Radiation On The LIver Function Test of Patients With Thoracic and Abdominal Tumors During Radiotherapy. Journal of Paramedical Sciences, 7(3), 8-12. 